\title{
From the "Annales de l'École Nationale des Eaux et Forêts" to the "Annals of Forest Science", eighty years of forestry science publications in France
}

\author{
Gilbert Aussenac* \\ Chief Editor of the Annals of Forest Science
}

INRA, Centre de Nancy, 54280 Champenoux, France

(Received 16 January 2002; accepted 15 February 2002)

\begin{abstract}
At the beginning of the 21st century we thought it would be interesting to take stock of the situation after 80 years of publication in the field of forestry science in France. The "Annals of Forest Science" is rooted in a long history of forest science publications, which began at the beginning of the 20th century with the Annales de l'École Nationale des Eaux et Forêts. Various changes taking the evolution of science and the international scientific context into account have allowed this journal to remain present in 2001. At present, in spite of the creation of new specialised journals, either in basic scientific disciplines (physiology, biology, genetics) or in more general fields concerning the environment or global change, the Annals of Forest Science, indexed in most of the large international data bases, still aims to be a specialised and efficient journal bringing together articles concerning trees, wood quality and forest ecosystems in one publication.
\end{abstract}

forest science / publication

Résumé - Des Annales de l'École Nationale des Eaux et Forêts à Annals of Forest Sciences, quatre-vingts ans de publications en sciences forestières en France. En ce début de XXI ${ }^{\mathrm{e}}$ siècle, il nous apparaît intéressant de faire le point sur 80 ans de publications dans le domaine de la science forestière en France. Annals of Forest Science trouve ses racines dans une histoire déjà ancienne, de publications de science forestière, qui a commencé au début du XX ${ }^{\mathrm{e}}$ siècle avec les Annales de l'École Nationale des Eaux et Forêts et s'est poursuivie avec les Annales des Sciences forestières. Différentes adaptations tenant compte de l'évolution des sciences et du contexte scientifique international ont permis à cette publication d'être encore présente en 2001. À l'heure actuelle, face à la création de nouvelles revues spécialisées soit dans des disciplines scientifiques de base (physiologie, biologie, génétique) soit dans des problématiques plus générales concernant notamment l'environnement ou les changements globaux, Annals of Forest Science, indexé dans la plupart des grandes bases de données internationales, a encore l'ambition d'être un support spécialisé et performant, rassemblant dans une même publication des articles concernant les arbres, le bois et les écosystèmes forestiers.

sciences forestières / publication

\section{INTRODUCTION}

At the beginning of the 21 st century we thought it would be interesting to take stock of the situation after 80 years of publication in the field of forestry science in France.

In France, forestry science began with Duhamel du Monceau in the middle of the 18 th century, but is was only a century and a half later that it was really developed, with the introduction of experimental methods, when environmental factors were taken into account and with the integration of recent progress in plant biology. We must remember that the Royal Forestry School of Nancy was founded in 1823 and that the first Forest Research Station was created in 1882.

At the end of the 19th century and the beginning of the 20th century, within the general context of a rapid development of science and technology, in France there was a

* Correspondence and reprints

Tel.: 03833940 25; fax: 03833940 69; e-mail: aussenac@ nancy.inra.fr 
profound change of ideas in the fields of plant biology and silviculture. Until then scientific knowledge was not advanced enough to understand how a biological system as complex as that of the forest, functioned. Geobotany did not exist yet, and the study of conditions related to the presence and growth of plants was not high developed, even if foresters had already characterised the behaviour of certain species. This period saw the emergence of sciences like ecology and phytosociology, taking into account functional relationships linking plants with climatic and soil conditions, and competition phenomena between living organisms. Pedology, another discipline essential for silviculture, also developed then.

In France at that time, foresters were confronted with considerable problems concerning the reconstitution of the forests, which had been ruined by over-exploitation after the Revolution of 1789, and the restoration of land in the mountains.

It was also the moment of a depth exploration of different countries (especially in the New World and Asia); then botanists and foresters had discovered new tree species likely to be useful for replanting. They still had to learn about their performance and capacity to adapt and acclimatise to the various regions of French forestry.

It was in this general context that forestry research developed in France, and the need to publish the results of this work in a specialised journal become evident.

\section{HISTORY OF FORESTRY SCIENCE PUBLICATIONS IN FRANCE}

In France, the first forestry science journal "Les Annales de l'École Nationale des Eaux et Forêts" was created in 1923. At that time a specialised journal was required to publish the research work of the Forestry Research Station, which was part of the École Nationale des Eaux et Forêts. Until then work had been published in scientific journals, which were not dedicated specifically to forests. The first 16 volumes, consisting of 33 sections (with a $15.5 \times 23.5 \mathrm{~cm}$ format) were, in theory, published annually, but in fact they were a little irregulars, especially during the second world war. From 1960, the "Annales de l'École Nationale des Eaux et Forêts" consisted of 4 sections, with about 600 pages per year.

In 1964, following the creation of National Centre of Forestry Research as a part of INRA (National Institute of Agronomic Research), the title changed and the "Annales de l'École Nationale des Eaux et Forêts" became the "Annales des Sciences Forestières". The intention was to modify the Annals into a journal able to accept both works from the Forestry School and from INRA research workers. However manuscripts offered by scientists outside the organisations were also accepted. French was the official publication language, but occasional papers were published in German or
English. The annals were considered as a means of exchanging ideas with publications from other foreign research institutes, especially those belonging to the International Union of Forest Research organisations (IUFRO).

In the 1980's, there was a progressive evolution towards more papers from national or international scientist:

- From 1984, manuscripts in English were accepted from non-French speakers; an Editorial Scientific Committee was created.

- In 1989, the journal became bilingual English-French; a Chief Editor was nominated. An editorial policy for the journal was created, which published the results of research in forests especially, in the fields of ecology, silviculture, genetics, physiology, damage to forests (entomological or pathological causes) and wood quality, in the form of original articles, summary articles and notes.

- In 1990, the journal changed from 4 to 6 numbers per year.

- In 1999, the title changed to reflect the increase in the number of papers published in English, written by a majority of foreign, but also French authors, and the "Annales des Sciences Forestières" became the "Annals of Forest Science", with 8 numbers per year and a larger format of $21.5 \times 27 \mathrm{~cm}$.

- In 2000, an associate Chief Editor was nominated for North America, so that papers could be received directly from North American authors.

\section{AN OVERVIEW OF THE EVOLUTION OF EDITORIAL POLICIES}

Like most scientific journals, the Annals have undergone profound modifications and have changed progressively from a predominantly French journal to an international one, publishing articles in English and French, from authors from all over the world. In figure 1, a rapid evolution after 1985 can be seen. After 1995, the percentage of papers in English was over $75 \%$, while the percentage of articles by foreign authors is now over $70 \%$. In order to disseminate the results of research more quickly, since 1989 the journal has published papers from congresses or colloquiums in the form of special or thematic issues after being refereed.

Since 1989, the following issues have been published:

- Forest Tree Physiology, Ann. Sci. For. 46 (1989) 1-875.

- Genetic of oaks, Ann. Sci. For. 50 (1993) 3-467.

- Improvement and silviculture of oaks, Ann. Sci. For. 6, 50 (1993) 529-632.

- Wood quality, IUFRO S5-01, Ann. Sci. For. 3, 51 (1994) 201-344.

- Site classification and evaluation, IUFRO S1.02.03, Ann. Sci. For. 6, 52 (1995) 521-680. 


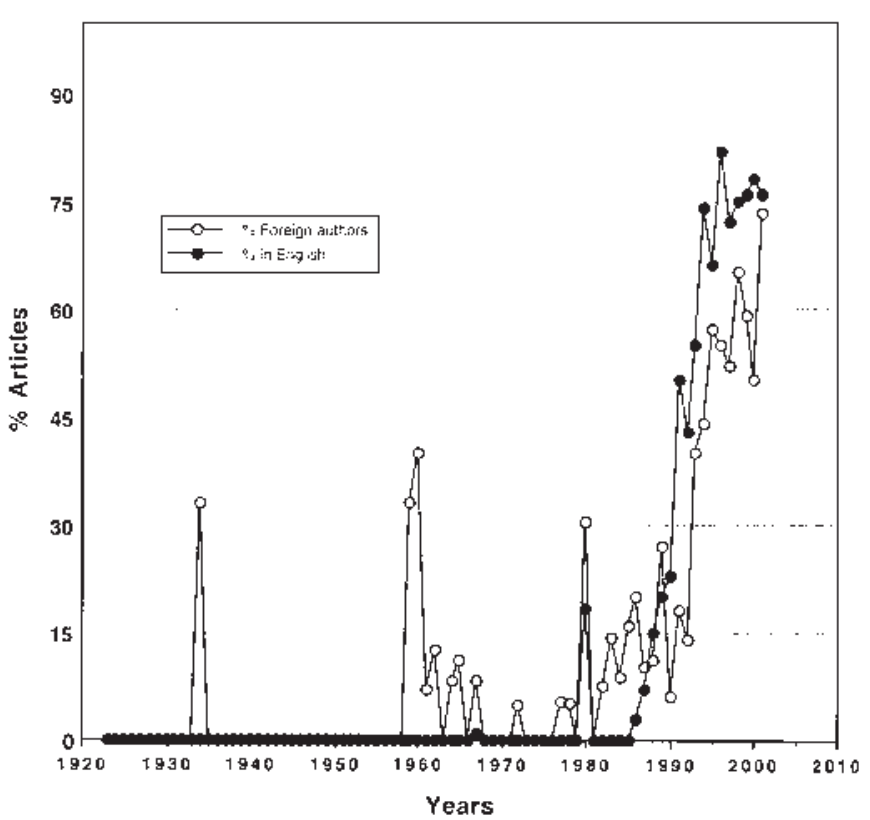

Figure 1. Annual evolution of the percentage of articles from foreign authors an the percentage of articles in English from 1923 to 2001.

- Ecology and physiology of oaks in a changing environment, Ann. Sci. For. 2/3, 53 (1996) 161-800.

- Water flux regulation in forest stands: an activity of BAHC and Euroflux, Ann. Sci. For. 5/6, 55 (1998) 1-276.

- 2nd International Workshop on Functional-Structural tree models, Ann. For. Sci. 5/6, 57 (2000) 393-622.

The referees are of various nationalities and in 2001, 57\% of the total number of referees were foreigners.

During this profound evolution, apart from the nationality of the authors, the change to English has also resulted in a profound modification in the readership, which was originally French-speaking, but it is now world-wide. Another very important difference worth noting, is that from the beginning until the 1980's, the readership consisted of a large number of French-speaking forest managers, but since then, partly due to the publication of very specialised scientific papers, and partly due to the higher proportion of papers in English, this readership has declined. Even though this process is understandable, as scientific papers are more relevant to research workers, it is a shame, in terms of speed of diffusion of scientific information that the forest managers have turned away from this type of publication. The problem of simplifying the results of scientific research for the general public, especially the articles published in scientific journals is a big challenge for the forestry community. In France, the diffusion of results of forestry research to the general public is the responsibility of several journals, for example the Revue Forestière Française (French Forestry Journal), Forêt Entreprise (Forest Enterprises), Arborescence, and Forêt Privée (Private Forests).
Up to the 1980's, a large proportion of forestry research in French laboratories was published in the Annales, but this is not the case in 2001. French scientists frequently publish their work in other international journals as well.

At first the journal was published directly by the Forestry School and then by INRA, but in 1989 to ensure a better distribution, it was passed to a private editor, Elsevier France, and then in 2000 to EDP Sciences. Finally the Annales des Sciences Forestières, and now the Annals of Forest Science is indexed in the large international data bases, and it is possible to consult it online on the Web site: http: //www.edpsciences.org.

Concerning the contents of the journal, the type and number of articles published has changed profoundly over the years. At first there were few manuscripts with a large number of pages, which were mainly monographs $[4,5,10,32]$ or texts derived from theses $[1,18,21,24,33]$ resulting from research work carried out over several years. Later, especially between 1965-1970, the mean number of pages per paper decreased (figure 2) while the number of pages published increased. This evolution reflected the development of experimental techniques and methods allowing one to study phenomena more quickly than in the past. This change, which is observed on a world-wide scale, can also be explained by the convergence of two tendencies: partly the desire of authors to transmit the results of their research more rapidly, and partly the pressure by institutes financing research to obtain the rapid publication of work, to be able to evaluate the quality of research workers and laboratories better.

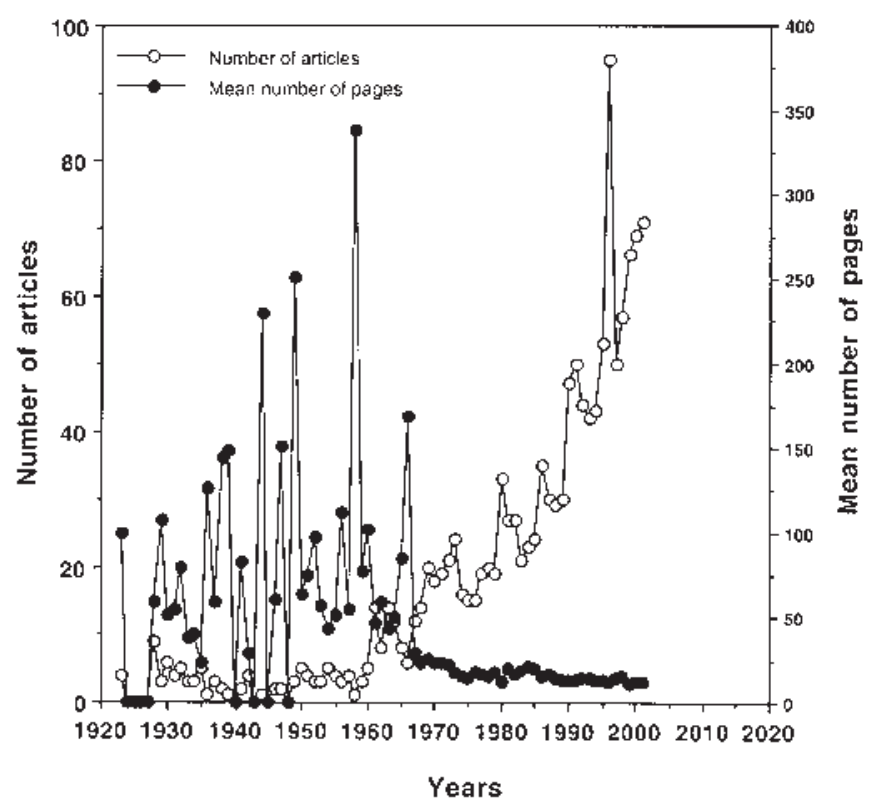

Figure 2. Annual evolution of the number of pages and the mean number of pager per article between 1923 and 2001. 
Theses and monographs are not published in the journal now. They are sometimes published as specific publications in book form by other editors.

It is also interesting to examine the evolution of the subjects treated in the papers published since the beginning in 1923 to the present day in 2001. During this long period papers covered a wide range of subjects: silviculture, forest management, ecology, ecophysiology, physiology, soils and nutrition, forest damage (insect attack, pathogenic fungi), improvement of forest trees and genetics, wood quality, forestry economics, biomathematics and even, at certain times, wild animals, hydrobiology, grazing [26] and forestry engineering $[11,25]$. The latter four subjects were mainly present in the early years of the Annales de l'École des Eaux et Forêts and are not published in the Annals of Forest Science anymore.

Figure 3 shows a comparison of the percentage of papers published (as a \% of the total) during the period from 1923 to 2001 , for the subjects covered most frequently, over $5 \%$. Ecophysiology represents $23 \%$ of the articles published; other themes like improvement and genetics, ecology, silviculture, forest damage, wood, and soils and nutrition only represent $10-15 \%$ each of the total. Physiology only represents $5 \%$ of the total.

In figure 4 one can see the evolution of the 7 main themes in detail (as a $\%$ of the total annual number of pages) from 1923 to 2001 . Using a few examples, it can be seen that papers concerning silviculture [16, 22, 30], ecology [14, 28], wood quality [3,17] and forest damage [15] have been present since the beginning of the publication. One can also see

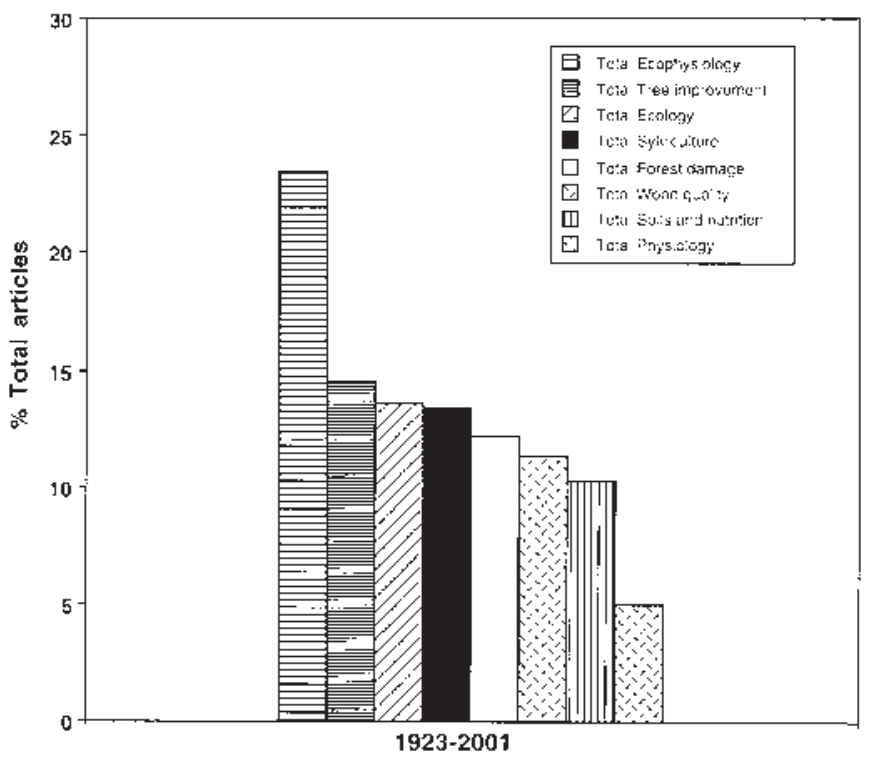

Figure 3. Comparison of the percentage of articles published (as a $\%$ of the total) between 1923 and 2001, in the most frequent subjects (over $5 \%$ ).

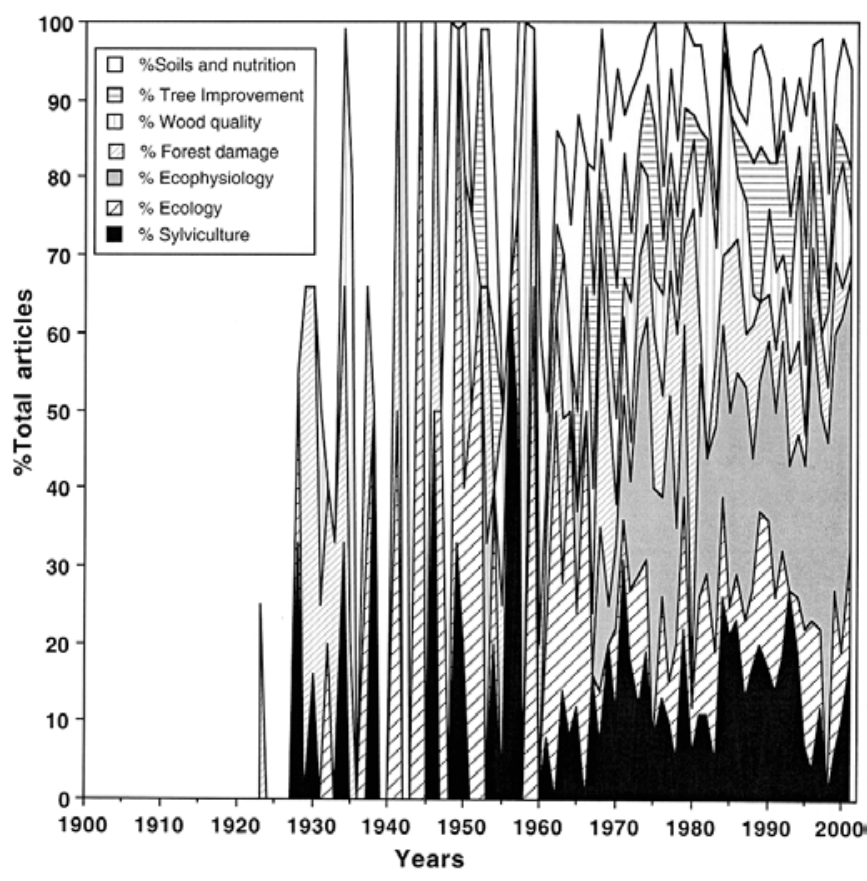

Figure 4. Annual evolution of the number of articles (as a $\%$ of the total number of articles) from 1923 to 2001 for the subjects treated most frequently at the present time.

that papers about forest soils, some of which are certainly reference documents $[7,8,23]$ and the nutrition are represented from the 1950's reflecting the rapid development of soil science in France at this time, and continue to be present regularly after 1965. Papers about ecophysiology [29] and genetic improvement of forest trees are not significantly present until after 1965 and reflect the general development of these subjects and also the inclusion of forest research into INRA (National Institute of Agronomic Research).

In the past 10 years, the development of forest research in the fields of fundamental processes of plant biology, genetics and the environment has oriented many French and foreign authors towards new specialised journals created in these different scientific fields; this explains the low percentage of physiology papers published during this period. Nevertheless the Annals of Forest Science continues to receive papers in these fields, especially when they have an obvious relationship with forest management or when they are the result of multidisciplinary research which is becoming essential, with regard to sustainable management, especially to increase our understanding of the way forest ecosystems function, and their relationships with the environment. Thus in the last few years, 2000-2001, there have be several papers on: mycorrhizas and their influence on tree growth $[2,6]$, genetics $[9,20,27]$, tree architecture modelling [31], modelling ecophysiological phenomena like evapotranspiration [12], carbon acquisition [19] and growth [13]. 


\section{CONCLUSION}

The "Annals of Forest Science" is rooted in a long history of forest science publications, which began at the beginning of the 20th century with the Annales de l'École Nationale des Eaux et Forêts. Various changes taking the evolution of science and the international scientific context into account have allowed this journal to remain present in 2001.

At present, in spite of the creation of new specialised journals, either in basic scientific disciplines (physiology, biology, genetics) or in more general fields concerning the environment or global change, the Annals of Forest Science, indexed in most of the large international data bases, still aims to be a specialised and efficient journal bringing together articles concerning trees, wood quality and forest ecosystems in one publication.

\section{REFERENCES}

[1] Bartoli Ch., Études écologiques sur les associations forestières de la Haute Maurienne, Ann. Sci. For. 3 (1966) 433-749.

[2] Boukcim H., Mousin D., Effect of P-fertilisation on the mycorrhization, growth and nutrition $(\mathrm{P}, \mathrm{N})$ of Cedrus atlantica Manetti seedlings inoculated in nursery with mycelia of Tricholoma tridentinum Sing. var. cedretorum Bon., Ann. For. Sci. 58 (2001) 289-300.

[3] Campredon J., Contribution à l'étude des propriétés élastiques des bois, Ann. Éc. Natl. Eaux For. Stn. Rech. Exp. 3 (1935) 251-288.

[4] Debazac E.F., La végétation forestière de la Kroumirie, Ann. Éc. Natl. Eaux For. Stn. Rech. Exp. 16 (1959) 1-34.

[5] Devèze M., La grande réformation des forêts royales sous Colbert (1661-1680), Première partie, Ann. Éc. Natl. Eaux For. Stn. Rech. Exp. 19 (1962) 1-167.

[6] Di Battista C., Bouchard D., Martin F., Genere B., Amirault J.M., Le Tacon F., Survival after outplanting of the ectomycorrhisal fungus Laccaria bicolor S 238 N inoculated on douglas fir (Pseudotsuga menziesii (Mirb) Franco) cutines, Ann. For. Sci. 59 (2002) 81-92.

[7] Duchaufour Ph., Recherches écologiques sur la chênaie atlantique, Ann. Éc. Natl. Eaux For. Stn. Rech. Exp. 11 (1948) 1-332.

[8] Duchaufour Ph., Bonneau M., Debazac E.F., Pardé J., Types de forêt et aménagement : la forêt de la Contrôlerie en Argonne, Ann. Éc. Natl. Eaux For. Stn. Rech. Exp.18 (1961) 1-44.

[9] Dulci F., Proietti R., Favre J.M., Allozyme assessment of genetic diversity within the relic Sicilian fir Abies nebrodensis (Lojac.) Mattei., Ann. For Sci. 56 (1999) 345-355.

[10] Fourchy P., Étude sur l'écologie et la sylviculture du mélèze : I'écologie du mélèze particulièrement dans les Alpes françaises, Ann. Éc. Natl. Eaux For. Stn. Rech. Exp. 13 (1952) 1-134.

[11] Garavel L., Éléments pour l'étude des projets de travaux contre les avalanches, Ann. Éc. Natl. Eaux For. Stn. Rech. Exp.14 (1955) 223-260.

[12] Granier A., Loustau D., Breda N., A generic model of forest canopy conductance dependent on climate, soil water availabilty and index leaf area, Ann. For Sci. 57 (2000) 755-765.

[13] Guilley E., Hervé J.C., Huber F., Nepveu G., Modelling variability of within-ring density components in Quercus petraea Liebl. with mixed-effect models and simulating the influence of contrasting silvicultures on wood density, Ann. For Sci. 56 (1999) 449-458.

[14] Guinier Ph., Les associations végétales et les types de forêts du Jura français, Annales ENEF 4 (1932) 262-282.

[15] Hubault E., Invasions d'insectes xylophages dans les peuplements résineux des Vosges alsaciennes, Ann. Éc. Natl. Eaux For. Stn. Rech. Exp. 1 (1923) 109-130.

[16] Huffel G., Les méthodes de l'aménagement forestier en France. Étude historique, Ann. Éc. Natl. Eaux For. Stn. Rech. Exp.12 (1927) 1-229.

[17] Iablokoff A.Kh., Action des facteurs écologiques sur la structure et les propriétés mécaniques du bois d’Épicéa (Picea excelsa Link.), Ann. Éc. Natl. Eaux For. Stn. Rech. Exp. (1955) 279-318.

[18] Illy G., Recherches sur l'amélioration du pin maritime, Ann. Sci. For. 23 (1966) 769-944.

[19] Le Roux X., Lacointe A., Escobar-Guttierez A., Le Dizès S., Carbon based models of individual tree growth: A critical appraisal, Ann. For. Sci. 58 (2001) 469-506.

[20] Mariette S., Chagné D., Decroocq S., Vendrim G.G., Lalanne C., Madur D., Plomion C., Microsatellite markers for Pinus pinaster Ait., Ann. For. Sci. 58 (2001) 203-206.

[21) Nahal L., Le Pin d'Alep (Pinus halepensis Mill.). Étude taxonomique, phytosociologique, écologique et sylvicole, Ann. Éc. Natl. Eaux For. Stn. Rech. Exp.19 (1962) 473-686.

[22] Pardé J., Douglas et tables de production, Ann. Éc. Natl. Eaux For. Stn. Rech. Exp. 15 (1956) 139-168.

[23] Plaisance G., Les sols à marbrures de la forêt de Chaux, Ann. Sci. For. 22 (1965) 437-680.

[24] Polge H., Établissement des courbes de variation de la densité du bois par exploration densitométrique de radiographies d'échantillons prélevés à la tarière sur des arbres vivants. Applications dans les domaines technologiques et physiologiques, Ann. Sci. For. 23 (1966) 1-187.

[25] Poncet A., Réflexions sur quelques données récentes pour le contrôle de l'érosion torrentielle et plus spécialement pour sa mesure, Ann. Éc. Natl. Eaux For. Stn. Rech. Exp. 18 (1961) 619-646.

[26] Prax J., Le rétablissement de l'équilibre agro-sylvo-pastoral et la mise en valeur forestière du bassin supérieur de l'Agout, Ann. Ec. Natl. Eaux For. Stn. Rech. Exp. 12 (1951) 469-526.

[27] Ribeiro M.M., Leprovost G., Gerber S., Vendramin G.G., Andizel M., Decroocq S., Marteau A., Mariette S., Plomion C., Origin identification of maritime pine stands in France using chloroplast simple-sequence repeats, Ann. For. Sci. 59 (2002) 53-62.

[28] Rol R., Contribution à l'étude de la répartition du Sapin, Ann. Éc. Natl. Eaux For. Stn. Rech. Exp. 6 (1937) 227-290.

[29] Roussel L., Recherches théoriques et pratiques sur la répartition en quantité et qualité de la lumière en milieu forestier : influence sur la végétation, Ann. Éc. Natl. Eaux For. Stn. Rech. Exp. 13 (1953) 295-402.

[30] Schaeffer L., Sur trois modes de calcul de la possibilité des futaies jardinées, Ann. Éc. Natl. Eaux For. Stn. Rech. Exp. 4 (1931) 1-84.

[31] Sievanen R., Nikinmaa E., Nygren P., Ozier-Lafontaine H., Perttunen J., Hakula A., Components of functional tree models, Ann. For. Sci. 57 (2000) 399-412.

[32] Trégubov V., Étude forestière sur le Picea omorica Panc., Ann. Éc. Natl. Eaux For. Stn. Rech. Exp. 5 (1934) 117-180.

[33] Venet J., Étude de la résistance mécanique des bois de mine en fonction des facteurs de la production forestière, Ann. Éc. Natl. Eaux For. Stn. Rech. Exp. 16 (1958) 1-338. 